\title{
Key Considerations for Planning the European Capital of Culture - The Case of Veliko Tarnovo
}

\author{
By Hannah Payer*
}

This paper presents principle planning issues for one of the biggest cultural initiatives introduced by the European Commission - the 'European Capital of Culture' programme. Evaluating the success of past European Capitals of Culture, scholars particularly emphasise the need for a well prepared and systematic planning approach. The main objective was to scrutinize how a city can successfully prepare itself for the title year and to develop a framework that depicts key planning areas for the programme. This framework in combination with guiding questions for each of the key planning areas aims to assist future applicant cities in the planning and preparation phase of the programme. One of these applicant cities is the Bulgarian town of Veliko Tarnovo. A comprehensive literature review provided a first insight into the topic. In a second step, in-depth interviews with former European Capitals of Culture experts were conducted with the final aim to develop the aforementioned framework and guiding questions. Finally, the findings were applied to the city of Veliko Tarnovo and recommendations were given. The results indicate that during the planning phase particular attention needs to be paid to the field of organisation, marketing and communication as well as funding and infrastructure investment. Organisers ought to be precise on the aims and objectives of the programme, keeping in mind its stakeholders and the legacy they want to leave for after the title year.

\section{Introduction}

The 'European Capital of Culture' programme is a cultural initiative which started in 1985 as an idea of the Greek cultural minister Melina Mercouri and the French Minister for Culture and Communication Jack Lang. Their underlying aim with the development of the programme was to showcase different European cities and their role in developing European cultures (European Commission, 2009, p. 3). The idea was born at a time when the need to adapt to social and economic transformations, caused by the process of economic restructuring of the 1970s and early 1980s, was strong. Moreover, the development of cultural policies was seen as an instrument to diversify the

\footnotetext{
*Research and Project, IMC University of Applied Sciences Krems, Austria.
} 
local economic base and to expand economic industries such as leisure, tourism and media (Bianchini, 1993, p. 2).

Besides the main objective of bringing people in the member states and their culture in contact with each other, the purpose of the European Capital of Culture programme outlined by the European Commission (2011, para. 4) is

- to highlight the richness and diversity of European cultures,

- to celebrate the cultural ties that link Europeans together,

- and to foster a feeling of European citizenship.

Prior to the nomination as European Capital of Culture, the applicant city has to undergo different stages in an overall selection process. It can be divided into two main phases: The pre-selection and the selection phase. The preselection phase starts six years before the actual event. In a first step, each Member State concerned - two countries are invited each year to nominate cities - publishes a call for submission of applications addressed to cities in the country which are interested in the title. From this publication on, interested cities have ten months to present a general programme outline for the proposed year. The programme outline is assessed by a selection panel which takes into consideration the objectives and criteria of the programme. The panel creates a short-list of candidate cities. The cities on the short-list then have a period of nine months to complete their applications. The final action in the selection phase is the recommendation of a city in each country by a selection panel which consists of six experts appointed by the country in question and seven appointed by the European Institutions. After the nomination, a city then establishes a delivery organisation which is responsible for the planning and development of the programme (European Commission, 2010, p. 5).

Being selected as European Capital of Culture has become more competitive and demanding after an alteration of the selection criteria by the European Commission in 2006. In order to focus on the long-term effects of the cultural development of the city and region concerned, the two most important selection criteria for all capitals as of 2013 are 'European Dimension' and 'City and Citizens'. The criterion 'European Dimension' assesses the extent of the collaboration and exchange between artists from different European countries. The criterion 'City and Citizens' evaluates the integration of the people living in the city and its surroundings into the programme. They constitute main preconditions for gaining the title and therefore need to be considered carefully when planning the event (European Commission, 2009, p. 8).

Numerous studies (Balsas, 2004; Richards \& Wilson, 2004; Herrero et al., 2006; Shukla et al., 2006) on the role of the European Capital of Culture event indicate that a successful preparation and the realisation of the expected positive impacts are not an easy task as different aspects have to be taken into account. These include among others the management quality of the programme, support from business communities, political and local authorities as well as the general size and location of the event. 
The existing research points to the need for a well prepared and systematic planning approach while undergoing the selection process (Balsas, 2004; Richards \& Wilson, 2004; Herrero et al., 2006; Shukla et al., 2006). This is not only important for a successful nomination in the first place, but also for fulfilling the expectations of the different stakeholders such as the aforementioned business communities, political and local authorities or residents. The European Commission underlines the need for proper planning by stating that the "preparation phase of the event is of crucial importance for its success in accordance with the objectives of the event" (European Commission, 2006, p. 1).

Despite existing studies there is a limited amount of information available on factors which establish a successful planning phase. This paper addresses the gap on how a city can successfully prepare itself for the European Capital of Culture year.

In order to observe how a city can do so, the following sub research questions are posed:

- What are the lessons learned from past European Capitals of Culture?

- What are the main challenges in the planning phase of the European Capital of Culture year?

- What key aspects need to be considered in the planning phase of the European Capital of Culture programme?

The aim of this research is to answer these research questions, and based on the answers to develop a framework that depicts key management considerations. These key management considerations include guiding questions that together support potential and future European Capitals of Culture in the programme planning phase and consequently the title year itself.

\section{Methodology}

For the construction of a framework of key planning considerations, a qualitative research method in the form of in-depth expert interviews was applied. The interviews were conducted with ten former European Capitals of Culture experts during the period of November 2012 until January 2013. The aim of this type of interviews is to gain a profound insight into the topic and to reveal contextual information. Furthermore, expert interviews are a way to reveal the tacit knowledge gathered by the people involved in the topic (Ambrosini \& Bowman, 2011, p. 820).

Participants were sourced by accessing publically available documents on former European Capitals of Culture. As the research topic focused on the planning phase for the European Capital of Culture, and particularly the management of this phase, former managing directors, chief executive directors or responsible department managers were contacted. The knowledge 
of the participants acquired in the planning and management of the programme was of particular interest. An introductory email was sent to participants seeking consent to participate, followed by phone communication. All but one of the interviews was conducted by telephone. Participating experts represented the former European Capitals of Culture of Graz 2003, Cork 2005, Liverpool 2008, Stavanger 2008, Linz 2009, Ruhr 2010, Pécs 2010, Turku 2011, Guimarães 2012 and Maribor 2012.

To facilitate coverage of relevant and important topics during the interviews an interview guide containing eight open ended questions was developed and tested. Topics discussed in the interview included opinions about the selection criteria introduced in 2006, aspects and challenges relating to planning and how these were overcome, lesson learned from seeking and being nominated for the European Capital of Culture and recommendations for organisations wishing to become nominated for the programme.

Data analysis and coding was undertaken using the ATLASti software and according to the five phases of qualitative data analysis described by Yin (2011). In a first step codes were developed following the key questions from the interview guideline. In a next step, passages of the interviews were examined thematically to develop additional codes. The disassembled data was then reorganised into categories or themes. In total four main categories of codes were developed. These are 'Pre-phase considerations', 'Structure and organisation', 'Further key planning areas' and 'Lessons learned'. To obtain a better overview, these categories and their sub themes were put into a hierarchical coding tree. This coding tree then served as a basis for the development of the framework.

For the case study example of the city of Veliko Tarnovo a mixed research methods approach was applied. In order to gather information and data about the city's current tourism development, secondary data was investigated, for example from the Ministry of Economy, Energy and Tourism of Bulgaria (2012). Information about the application for the European Capital of Culture was obtained through expert interviews with the tourism director of the municipality and the Director of 'European integration, funds and programming'. An on-site observation in October 2012 complemented the research on the applicant city.

\section{Results}

The following part introduces one of the main outcomes of the research: the 'European Capital of Culture Strategic Planning Framework', a systematic planning tool for potential and future European Capitals of Culture. Thereupon, the set of guiding questions that complements the framework is presented. The case of Veliko Tarnovo is illustrated in the last subchapter and serves as an application example of the developed framework and guiding questions. 
Framework of Key Considerations for Potential European Capitals of Culture

Based on the results of the in-depth expert interviews a framework of key considerations with a set of guiding questions was developed. This framework, in combination with the guiding questions, presents a strategic planning tool for applicant cities by pointing out areas and issues which need particular attention. The framework (figure 1) is based on the coding tree which was used for the analysis of the interviews. The three categories of 'Pre-phase Considerations', 'Structure and Organisation' and 'Further Key Planning Areas' constitute the core of the framework. They set a path to the principal issues discussed by the experts which are regarded as key considerations for the planning of the programme.

Figure 1. ECoC Strategic Planning Framework

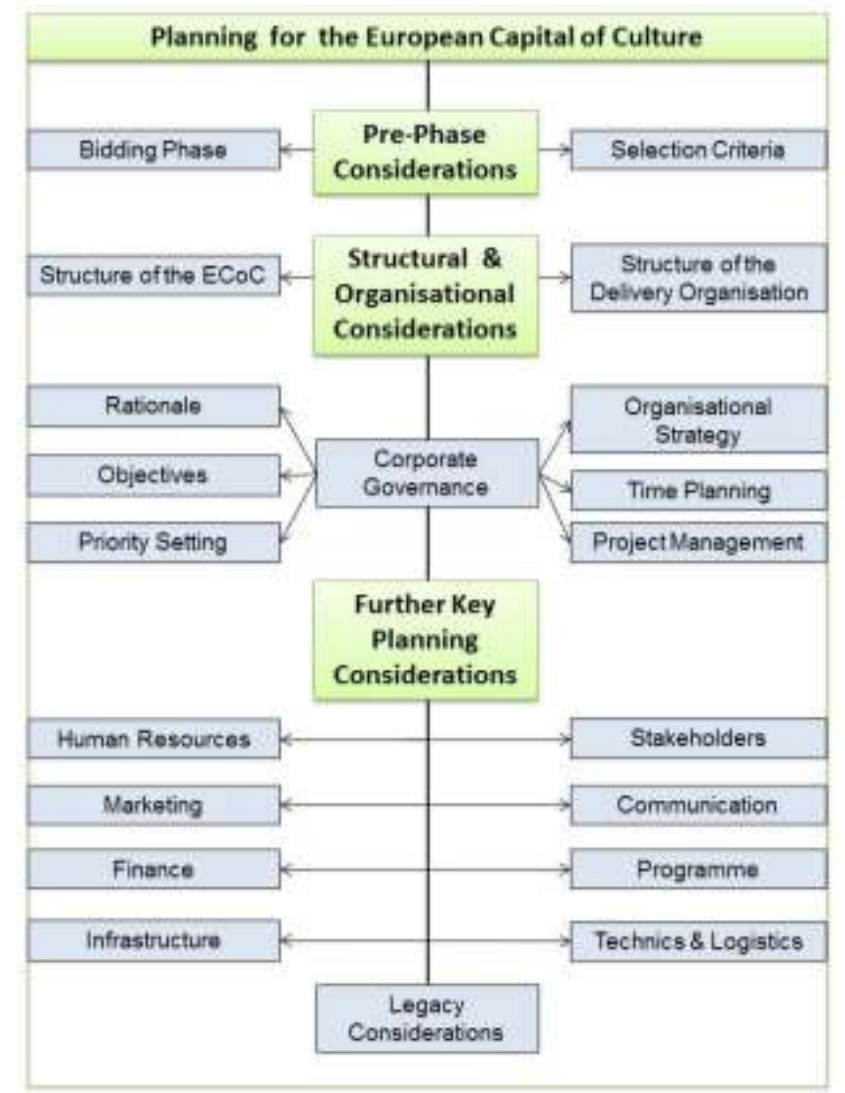

Within each of these key considerations, guiding questions were developed. These guiding questions take into account the experts' opinions and recommendations on the respective topics outlined in the framework. Table 1 summarises the guiding questions in the form of a checklist. 
Vol. 1, No. $4 \quad$ Payer: Key Considerations for Planning the European Capital...

Table 1. Guiding Questions for Future European Capitals of Culture

\begin{tabular}{|c|c|c|}
\hline & Topic & Guiding Questions \\
\hline \multirow{2}{*}{ 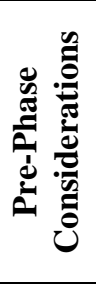 } & Bidding Phase & $\begin{array}{l}\text { - Is the bidding document precise enough? } \\
\text { - Is there room for adaption later on? } \\
\text { - What is the long term legacy of the event? }\end{array}$ \\
\hline & $\begin{array}{l}\text { Selection } \\
\text { Criteria }\end{array}$ & $\begin{array}{l}\text { - Does the programme reflect an own approach and does it } \\
\text { reflect the identity of the city? } \\
\text { - How is the identity of the city connected to Europe? } \\
\text { - How can the population be included in the programme? }\end{array}$ \\
\hline \multirow{9}{*}{ 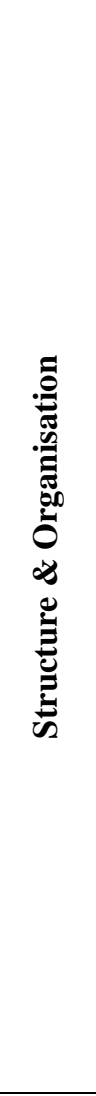 } & $\begin{array}{l}\text { Structure of the } \\
\text { ECoC }\end{array}$ & $\begin{array}{l}\text { - Which tasks should be outsourced and which tasks can be } \\
\text { done in house? } \\
\text { - Are there enough institutions present to support the } \\
\text { programme? }\end{array}$ \\
\hline & $\begin{array}{l}\text { Structure of the } \\
\text { Delivery } \\
\text { Organisation }\end{array}$ & $\begin{array}{l}\text { - Are experts from the bidding process taken on board of the } \\
\text { organisational team? } \\
\text { - Is the delivery organisation funded under public or private } \\
\text { law? } \\
\text { - Are clear communication and reporting structures } \\
\text { established within the company? } \\
\text { - Is a certain degree of political independence given? }\end{array}$ \\
\hline & $\begin{array}{c}\text { Corporate } \\
\text { Governance }\end{array}$ & $\begin{array}{l}\text { - Is there a clear focus of the programme? } \\
\text { - Is there a tool in place to measure the success? }\end{array}$ \\
\hline & Rationale & $\begin{array}{l}\text { - Why does the city participate in this programme? } \\
\text { - What does the city want to achieve with the programme? } \\
\text { - Is the cultural focus prevailing? }\end{array}$ \\
\hline & Objectives & $\begin{array}{l}\text { - Are objectives clearly stated? } \\
\text { - Are these objectives measurable? } \\
\text { - Are these objectives communicated to the relevant } \\
\text { stakeholders? }\end{array}$ \\
\hline & Priority Setting & $\begin{array}{l}\text { - Are clear priorities set with the key stakeholders and in } \\
\text { accordance with the objectives? }\end{array}$ \\
\hline & $\begin{array}{l}\text { Organisational } \\
\text { Strategy }\end{array}$ & $\begin{array}{l}\text { - What does the organisational strategy look like? } \\
\text { - How is the strategy going to be implemented? }\end{array}$ \\
\hline & Time Planning & - Is an adequate and realistic time plan in place? \\
\hline & $\begin{array}{c}\text { Project } \\
\text { Management }\end{array}$ & $\begin{array}{l}\text { - Are project management tools considered and used for } \\
\text { planning, organising and controlling? }\end{array}$ \\
\hline \multirow{2}{*}{ 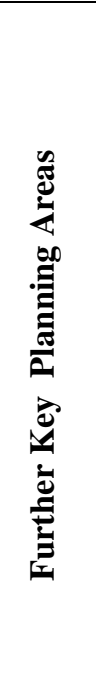 } & $\begin{array}{l}\text { Human } \\
\text { Resources }\end{array}$ & $\begin{array}{l}\text { - Are people with a suitable professional background } \\
\text { available? } \\
\text { - Is a culture of teamwork established? } \\
\text { - Are learning opportunities given? } \\
\text { - Are employees motivated on a regular basis? } \\
\text { - Are volunteers or interns involved? If so, do they have } \\
\text { suitable tasks? }\end{array}$ \\
\hline & $\begin{array}{l}\text { Stakeholders (e.g. } \\
\text { European } \\
\text { Commission, } \\
\text { politics, media, } \\
\text { general public, } \\
\text { artistic \& civic } \\
\text { organisations) }\end{array}$ & $\begin{array}{l}\text { - Are the key stakeholders identified? } \\
\text { - Do they support the programme? } \\
\text { - Are communication strategies for the different } \\
\text { stakeholders available? } \\
\text { - Can the general public actively participate in the } \\
\text { programme? } \\
\text { - Is cooperation with authorities on a local level } \\
\text { implemented? } \\
\text { - Is cooperation with former ECoC and the second ECoC of } \\
\text { the year considered? }\end{array}$ \\
\hline
\end{tabular}




\begin{tabular}{|c|c|}
\hline & $\begin{array}{l}\text { - Are possible drawbacks communicated to the } \\
\text { stakeholders? }\end{array}$ \\
\hline Marketing & $\begin{array}{l}\text { - Is a clear marketing message formulated? } \\
\text { - Is the target market identified? } \\
\text { - Is the tourism sector considered as a strategic marketing } \\
\text { partner? } \\
\text { - Are events or activities of the programme used as } \\
\text { marketing tool prior to the title year? }\end{array}$ \\
\hline Communication & $\begin{array}{l}\text { - Are communication activities based on the vision of the } \\
\text { programme? } \\
\text { - Are the aims and benefits of the programme } \\
\text { communicated? } \\
\text { - Is a story created for communication throughout the } \\
\text { process? } \\
\text { - Is a communication plan in place to respond to criticism } \\
\text { and negative reactions from the media? }\end{array}$ \\
\hline Finance & $\begin{array}{l}\text { - Are legally binding financial contracts with the main } \\
\text { funding bodies in place? } \\
\text { - Is financial controlling in place? } \\
\text { - Is money secured for possible budget shortages? }\end{array}$ \\
\hline $\begin{array}{l}\text { Technics \& } \\
\text { Logistics }\end{array}$ & $\begin{array}{l}\text { - Are technical and logistical issues planned from the very } \\
\text { beginning? }\end{array}$ \\
\hline $\begin{array}{c}\text { Cultural } \\
\text { Programme }\end{array}$ & $\begin{array}{l}\text { - Is the quality of the programme and the individual projects } \\
\text { checked and monitored? } \\
\text { - Is the programme balanced for the different target groups? }\end{array}$ \\
\hline $\begin{array}{l}\text { Infrastructure } \\
\text { Sustainability }\end{array}$ & $\begin{array}{l}\text { - Is a viable utilisation of the built infrastructure given after } \\
\text { the title year? } \\
\text { - Who will be responsible for the management and } \\
\text { maintenance of the infrastructure in the future? }\end{array}$ \\
\hline Legacy & $\begin{array}{l}\text { - Is a strategic development or legacy plan in place? } \\
\text { - Are all types of legacies (e.g. cultural infrastructure on the } \\
\text { one hand and skills development on the other) considered? }\end{array}$ \\
\hline
\end{tabular}

The questions ought to be addressed by the organisational team at the very beginning of the selection phase when drafting the programme and then continuously throughout the preparation phase.

\section{The Case of Veliko Tarnovo}

The established framework and guiding questions were applied to the Bulgarian city of Veliko Tarnovo. The municipality is currently a project partner of the European INTERREG CultTour project and aims to become European Capital of Culture in 2019. The IMC University of Applied Sciences Krems is part of the CultTour project consortium and with their research on key considerations for planning the European Capital of Culture seeks to support the city during their bidding process for the programme.

Veliko Tarnovo is located in the North of Bulgaria in the province Veliko Tarnovo County. The city is one of the oldest settlements in Bulgaria with its history dating back to more than five thousand years. However, today Veliko Tarnovo is particularly known due to its nomination as capital of the Second 
Bulgarian Empire in 1185 after the end of the Byzantine power. The town has a population of approximately 70000 people. The distance to the capital Sofia is around 240 kilometres (Ministry of Economy, Energy and Tourism of Bulgaria, 2012).

The main type of tourism present is cultural tourism (Boyadjiev \& Tzenova, 2012). After cultural tourism, the sector of events and congresses is predominant. Reviewing tourism advertising material (Municipal Tourist Information Center, n.d.) reveals that the main types of attractions in the area are museums, churches and monasteries as well as historical monuments. Besides man-made attractions many different events are staged including the "Stage of the Ages" event or the "International Folklore Festival" (Municipal Tourist Information Center, 2014).

The Municipal Tourist Agency of Veliko Tarnovo plays a central role in developing cooperation amongst tourism suppliers. Its main stakeholders are museums in the city, tour operators in order to market the city, surrounding municipalities and the currently 24 twin cities. Furthermore, the Agency considers developing an attraction pass that links several attractions in the city. For cooperation between accommodation providers in the city a local branch of the Bulgarian Hotel and Restaurant Association is present (Boyadjiev \& Tzenova, 2012).

An important aspect for tourism in the city is accessibility. At present there is one national road going through the city, however the construction of a highway is planned in the North of the city. The city has one small train station within the city and a bigger one in Gorna Oryahovitsa, which is around nine kilometres outside the city and is the main train station in central Bulgaria. Gorna Oryahovitsa also has an international airport but does not operate regular passenger flights at present. Within the city people can move by car, bus or foot (Boyadjiev \& Tzenova, 2012). The following figure combines the author's findings of the tourism analysis in a SWOT analysis.

During the course of the interview with the Director of the Tourist Agency of the municipality of Veliko Tarnovo, initial ideas and objectives for the strategy of the European Capital of Culture programme were described. The aims of the application as European Capital of Culture 2019 is, amongst others, the creation of new cultural branches, bringing together local artists with European ones, giving the local population an option to create ideas and the development of a long term strategy for the cultural life of the city. The focus is on young people. Based on these considerations, the findings of the methodological part and the SWOT analysis, first recommendations for applying and eventually also hosting the European Capital of Culture programme in 2019 were proposed by the author. They are presented in the consequent subchapters. 
Figure 2. Tourism SWOT Analysis of Veliko Tarnovo

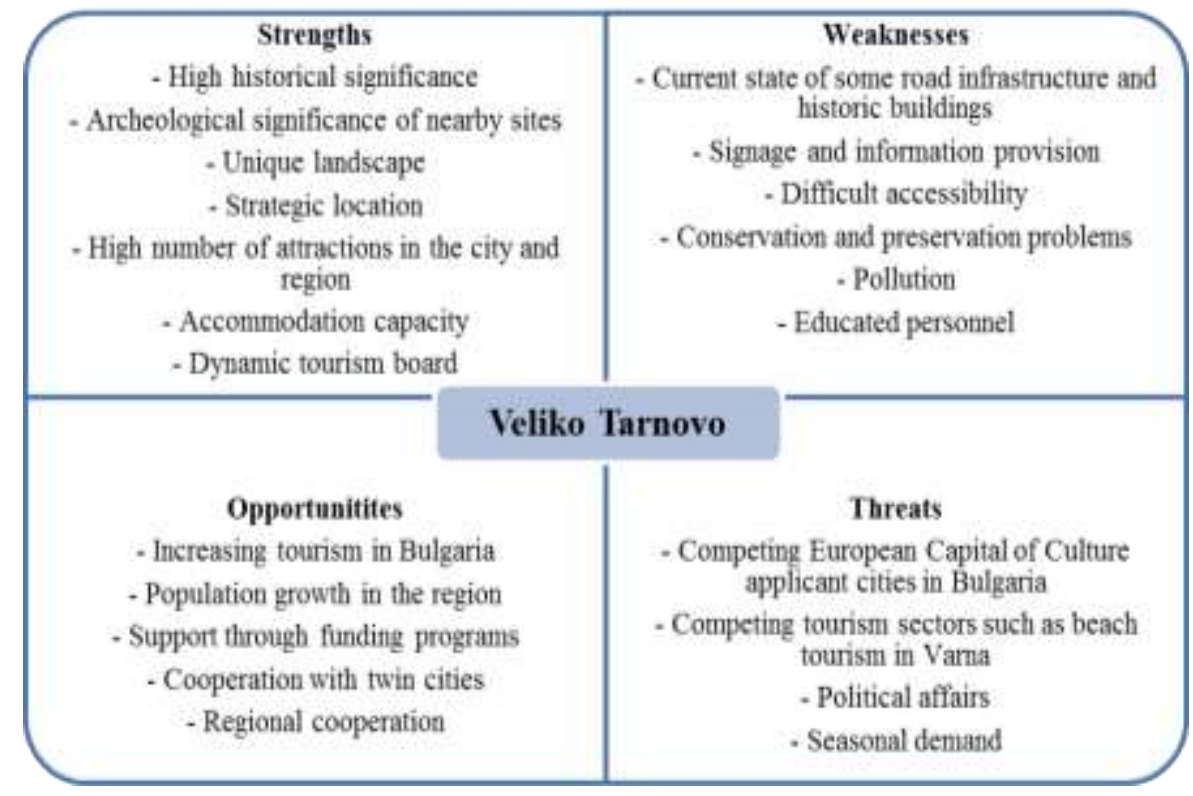

\section{Recommendation on 'Pre-Phase Considerations'}

- Create an application that reflects the identity of Veliko Tarnovo and allows for further artistic freedom once selected. The identity is particularly seen in the historical significance for Bulgaria and the cultural legacy delivered by the fortress and the monasteries.

- Include the growing younger population of the city in the programme and increase their cultural capacity by giving them the opportunities to engage in the organisation and the development of the programme through, for example, internships.

\section{Recommendations on 'Structure \& Organisation'}

- Take advantage of the variety of cultural institutions present in Veliko Tarnovo and develop programmes in collaboration with them. These institutions could be for example the museums focusing on the history of the place, but also the monasteries focusing on religion and the shops focusing on arts and craft.

- Establish a clear focus of the programme by taking into account the aim of developing a long term strategy for improving the cultural life of the city. This aims to increase the legacy of the programme.

- Decide on three to four main objectives for the programme such as the ones outlined in the strategy above. Make sure that these objectives can be measured at some point and are clearly articulated to the relevant stakeholders. Moreover, decide which objectives are the most important ones and have the highest priority. 


\section{Recommendations on 'Further Key Planning Areas'}

- Assess the potential of the people working in the tourism sector and create a learning opportunity for them to increase the general quality of the tourism services.

- Try to create a team where a good working atmosphere and solidarity is fostered from the very beginning.

- Work together with local authorities to work on problems such as pollution and conservation.

- Identify the key stakeholders of the city such as politicians, the population and the touristic infrastructure (e.g. hotels and restaurants) and try to involve them as early as possible to gain their support through smaller projects such as crowdsourcing.

- Create an interesting and fascinating story for national, but particularly international tourists, which are increasingly visiting Bulgaria. This story could be related to the history of the city, but also to the religious significance of the monasteries.

- Cooperate with the cultural facilities around Veliko Tarnovo, such as the Architectural Reserve Arbanassi, in order to create regional cohesion.

- Try to improve the road infrastructure and the condition of the older buildings of the city by seeking support through funding programmes.

- Think of establishing a "European Capital of Culture" shuttle service from bigger cities to ease accessibility.

- Provide for sufficient touristic information and signage to ease the orientation around the city.

\section{Discussion}

The research first and foremost indicated the need for a strategic planning approach of the programme as the experts particularly revealed an overall lack of planning during the selection and preparation phase. The delivery organisation plays the central acting body and its establishment is highly significant for all future actions. It is responsible for the successful planning and implementation of the programme which includes, amongst other activities, organisation, programme development, human resources, marketing and communication as well as funding. The delivery organisation, however, cannot act as a closed system and cooperation and coordination with its stakeholders is therefore one of the prevailing issues. This was clearly identified as a key recommendation made to Veliko Tarnovo.

One of the main suggestions is therefore to invest as much time as possible into the bidding for the European Capital of Culture title considering fundamental issues such as the programme objectives, time and resource planning as well as finance, which are core areas that are also considered in traditional project management. Additionally, by setting clear priorities 
managing expectations of various stakeholders will be easier as they know the priorities of the organisation.

\section{Conclusion}

This study has examined the challenges and key management areas inherent in the planning of the European Capital of Culture programme. It involved interviews with experts from ten former European Capitals of Culture. Within the study several key themes emerged. These are for example the selection criteria in the bidding phase, the initial structure and organisation of the programme or further key planning areas including human resources, finance or marketing and communication.

It can be concluded from this study that the success of the European Capital of Culture programme is determined by several different aspects. Many of these aspects such as corporate governance or financial planning need to be considered at a very early stage and are particularly important with regards to the selection phase. It can be argued that without this research some cities might continue to struggle in the planning phase, not being able to maximise potential benefits while minimising potential negatives.

A final recommendation would therefore be to start the European Capital programme by analysing one's current assets, elaborating on the vision and objectives and then take enough time to realistically match available resources with the vision and objectives. A key consideration in relation to the latter should be the extent to which future generations can benefit. Moreover, as emphasised by various experts throughout the interviews, the programme has a cultural focus and this means that cities should focus on revealing their unique cultural heritage. The 'ECoC Strategic Planning Framework' developed from this research is the ideal tool to support that. It could, for example, form the basis of initial meetings between stakeholders around deciding on whether to bid or not. It furthermore provides a 'reality' check and assists cities to understand some of the key challenges and issues they will face throughout the process.

Its application and its guiding questions are an important tool for upcoming applicants for the European Capital of Culture. Their role is to improve the quality of the applications and the planning of the programme as a whole.

Acknowledgments: Special thanks go to the project consortium of the European CultTour project which does research on the topic of cultural (garden) heritage as a focal point for sustainable tourism development in South East Europe. CultTour is an INTERREG IVB Project, funded by the EU within the framework of the ETC (European Territorial Co-operation), the South East Europe Programme (SEE) and co-funded by ERDF (European Regional Development Fund). 


\section{References}

Ambrosini, V., \& Bowman, C. 2001. Tacit Knowledge: Some Suggestions for Operationalization. Journal of Management Studies, 38, 6, 811-829.

Balsas, C. 2004. City Centre Regeneration in the Context of the 2001 European Capital of Culture in Porto, Portugal. Local Economy, 19, 4, 396-410.

Bianchini, F. 1993. Remaking European cities: the role of cultural policies. In F. Bianchini, \& M. Parkinson, Cultural policy and urban regeneration. The West European experience. (pp. 1-20). Manchester University Press, Manchester.

Boyadjiev, T., \& Tzenova, M. 2012. Interview on October 19, 2012 at the Municipality of Veliko Turnovo. Veliko Turnovo.

European Commission 2006. Decision No 1622/2006/EC of the European Parliament and the Council establishing a Community action for the European Capital of Culture event for the years 2007 to 2019. Official Journal of the European Union, L 304/1-6.

European Commission 2009. European Capitals of Culture: The Road to Success. From 1985 to 2010. Retrieved August 21, 2012, from http://ec.europa.eu/cultu re/pub/pdf/ecoc_25years_en.pdf

European Commission (2010). The Guide for Cities applying for the Title of European Capital of Culture. Downloaded on July 3rd, 2012, from European Commission. Culture: http://ec.europa.eu/culture/pdf/doc633_en.pdf.

European Commission 2011. European Capitals of Culture. Retrieved September 14, 2012, from European Commission. Culture: http://ec.europa.eu/culture/ourprogrammes-and-actions/doc413_en.htm

Garcia, B. 2005. Deconstructing the City of Culture: The Long-term Cultural Legacies of Glasgow 1990. Urban Studies, 42, 5/6, 841-868.

Herrero, L., Sanz, J., Devesa, M., Bedate, A., \& del Bario, M. 2006. The Economic Impact of Cultural Events: A Case Study of Salamanca 2002, European Capital of Culture. European Urban and Regional Studies, 13, 1, 41-75.

Ministry of Economy, Energy and Tourism of Bulgaria 2012. Veliko Tarnovo. Retrieved October 12, 2012, from Bulgaria Travel: http://bulgariatravel.org/en/ object/15/Veliko_Tyrnovo_grad

Municipal Tourist Information Center. n.d. The Region of Veliko Tarnovo. Tourist Information Center, Veliko Tarnovo.

Municipal Tourist Information Center 2014. Cultural tourism. Retrieved May 8, 2014, from http://www.velikoturnovo.info/en/cultural-tourism/.

Richards, G., \& Wilson, J. 2004. The Impact of Cultural Events on City Image: Rotterdam, Cultural Capital 2001. Urban Studies, 41, 10, 1931-1951.

Shukla, P., Brown, J., \& Harper, D. (2006). Image Association and European Capital of Culture: Empirical Insights through the Case Study of Liverpool. Tourism Review, 60, 2, 6-12.

Yin, R. 2011. Qualitative Research from Start to Finish. The Guilford Press, New York. 